\title{
TINJAUAN KRITIS TERHADAP PENDIDIKAN AGAMA MULTIKULTURAL BARBARA WILKERSON
}

\author{
Slamet Santoso \\ Sekolah Tinggi Theologia Abdiel \\ 62slametsantoso@gmail.com
}

\begin{abstract}
This article deals with the thought of Barbara Wilkerson that discusses the religious education in the context of the multiple culture. The writer argues that Wilkerson's theory can give contribution to develop the religious education of the multiple culture in Indonesian context. It is important to be noted that Wilkerson does not answer directly to the problems of the multiple culture in Indonesia context. The writer also discusses critically Wilkerson's theory, especially when such a theory is applied in Indonesian context.
\end{abstract}

Keywords: Culture, Wilkerson's theory, Religious Education, Indonesian Context.

\section{Pendahuluan}

Masyarakat Indonesia sejak jaman kemerdekaan tanggal 17 Agustus 1945 sudah berikrar bahwa negara Indonesia adalah negara majemuk atau multikultural yang terdiri dari berbagai etnis, ras, agama dan budaya serta diikat dalam kesatuan yaitu Negara Kesatuan Republik Indonesia (NKRI). Kemajemukan tersebut tersirat dalam semboyan yang cukup terkenal yaitu Bhineka Tunggal Ika dengan makna meskipun berbeda-beda, tetapi tetap satu.

Bangsa Indonesia yang multikultural dari satu sisi dapat memberi kekuatan, namun pada sisi lain dapat juga menjadi sumber konflik. Masyarakat multikultural perlu ditata dan disikapi dengan tindakan moral yang baik dan tepat oleh setiap warga negara Indonesia. Kehidupan multikultural tidak hanya terdapat dalam suatu negara, namun gereja juga mengalami dan berinteraksi dengan masyarakat multikultural. Para ahli Pendidikan Multikultural sudah banyak menulis tentang Pendidikan Multikultural, contohnya Tilaar H.A.R. Tilaar, yang menulis buku berjudul "Multikulturalisme, Tantangan Global Masa Depan dalam Transformasi Pendidikan Nasional". Selanjutnya ada penulis yang menghubungkan realitas multikultural dengan pendidikan agama.

Salah satu buku yang membahas tentang Pendidikan Agama Multikultural adalah Barbara Wilkerson. Buku Wilkerson diharapkan dapat memberi wawasan bagi Pendidikan 
Multikultural di Indonesia. Meskipun buku Wilkerson tidak langsung dapat menjawab persoalan masyarakat Indonesia yang multikultural, namun beberapa prinsip Pendidikan Multikultural yang ditulisnya dapat memberi kontribusi bagi kemajuan dan perkembangan Pendidikan Multikultural di Indonesia. Dibawah ini penulis akan melakukan tinjauan kritis terhadap pandangan Wilkerson tentang Pendidikan Agama Multikultural.

\section{Konteks Membentuk Teori Pendidikan Kristiani}

Pada era globalisasi banyak terjadi perubahan yang signifikan, sehingga dapat mempengaruhi kehidupan manusia di dunia ini. Teori bukan lahir atau hadir dalam ruang yang kosong, namun dalam ruang itu ada dinamika sosial kultural atau sebuah praksis, sehingga teori dipengaruhi dan dibentuk oleh konteksnya. Konteks masyarakat telah mempengaruhi dan membentuk teori Pendidikan Kristiani seperti yang disampaikan oleh Hope S. Antone yang mengutip Pamela Mitchell Legg. Dalam melaksanakan teori Pendidikan menunjuk pada peran konteks yang vital. Dalam kerangka kerja ini, membuat suatu rencana pendidikan dimulai dengan memahami dan menggambarkan konteks atau persoalan yang dihadapi oleh komunitas. Dengan dimulai dari konteks, tujuan teori pendidikan menjadi suatu pengungkapan kemana pendidikan agama mengarah sambil menghadapi masalah dan kebutuhan masyarakat yang baginya teori tersebut dibuat. Maka teori pendidikan dibentuk oleh konteks masyarakat tertentu. Demikian pula Jack L. Seymour Seymour mendefinisikan Pendidikan Kristiani dipengaruhi oleh konteksnya.

Dalam artikel yang ditulis oleh Jack L. Seymour dan Donald E. Miller menjelaskan tentang konteks masyarakat dan terutama konteks jemaat menjadi pengaruh dan pembentuk bagi teori Pendidikan Kristiani. Menurut Seymour konteks dapat diungkapkan antara lain pertama, melalui munculnya teknologi dan transportasi yang lebih maju dan alat komunikasi yang semakin mengubah perilaku hidup manusia. Kedua, akibat dari teknologi yang maju muncul sikap individual dalam sebagian besar orang, seperti seseorang dapat menikmati TV, internet dll yang mengakibatkan orang semakin hidup dalam dunia maya dan mengisolasi dari kehidupan sosialnya.

Ketiga, dunia transportasi dan teknologi komunikasi mengakibatkan manusia melakukan migrasi ketempat lain, baik itu bisa bersifat lokal, nasional maupun ke luar negeri, yang kemudian terjadi proses interaksi dengan para imigran dari berbagai negara. Akibatnya munculnya berbagai budaya multikultural. Keempat, munculnya jurang pemisah antara kelompok orang kaya dan orang miskin. Perbedaan ini bukan hanya pada tingkat 
pribadi, lokal, namun terjadi di skala yang lebih besar yaitu antara negara kaya dan negara miskin. Kondisi demikian dapat menciptakan kekerasan pada diri manusia.

Kondisi di atas dapat memengaruhi pola hidup manusia, termasuk didalamnya adalah gereja sehingga dapat terjadi penurunan pada vitalitas jemaat. Jemaat atau gereja sebagai salah satu agen perubahan diharapkan dapat memberikan kontribusinya terhadap situasi dan kondisi masyarakat yang demikian. Pendidikan Kristiani yang hadir dalam konteks kekinian sudah tidak lagi mengajarkan dan menghafalkan serta mengulang-ulang statement atau kalimat-kalimat pernyataan iman dari orang-orang Kristen di abad yang lampau ${ }^{1}$. Pendidikan Kristiani yang kontekstual adalah pendidikan yang mampu berperan aktif dan memberi bantuan untuk menyelesaikan atau menangani isu-isu penting baik yang berhubungan dengan masalah pribadi atau sosial dalam terang Injil ${ }^{2}$.

Pendidikan Kristiani mengajarkan tradisi iman pertama yang dicatat dalam Alkitab sehingga orang-orang mengenali identitas Yesus dan turut mencari sumber-sumber untuk memahami kehendak Allah dalam kehidupan sehari-hari. Selanjutnya orang-orang percaya melakukan refleksi teologis ketika menghadapi isu-isu dan akan mengambil keputusan tentang bagaimana hidup dalam kondisi demikian. Pendidikan Kristiani perlu menyediakan ruang terbuka bagi mereka yang mempelajari tradisi iman dan memperhadapkan tradisi iman itu dengan masalah-masalah kehidupan serta berusaha untuk hidup setia kepada Allah. Maka Seymour merumuskan bahwa Pendidikan Kristiani adalah sebuah percakapan kehidupan, sebuah usaha untuk menggunakan sumber iman dan tradisi kultural dalam menghadirkan masa depan yang adil dan berpengharapan ${ }^{3}$. Christiani menambahkan bahwa Pendidikan Kristiani bukan sekadar kegiatan meneruskan dogma dari waktu ke waktu dan menghafalkannya, melainkan mempertemukan ajaran-ajaran gereja itu dengan kehidupan masa kini dalam percakapan, yang mengarah ke masa depan yang adil dan penuh pengharapan ${ }^{4}$.

Seymour melanjutkan definisinya dengan memetakan ada empat macam pendekatan terhadap Pendidikan Kristiani. Pendekatan-pendekatan itu adalah pendekatan instruksional atau pengajaran religius, perkembangan spiritual, komunitas iman dan transformasi sosial. Pendekatan instruksional atau pengajaran religius menekankan

\footnotetext{
${ }^{1}$ Tabita Kartika Christiani, Pendidikan Kristiani Berbasis Multikultural (Ungaran: Semarang, 2018), 1

${ }^{2}$ Jack L Seymour (ed), Memetakan Pendidikan Kristiani Pendekatan-Pendekatan Menuju Pembelajaran Jemaa. (Jakarta: BPK Gunung Mulia, 2016), 146.

${ }^{3}$ Ibid., 13.

${ }^{4}$ Tabita Kartika Christiani, Pendidikan Kristiani Berbasis Multikultural (Ungaran: Semarang, 2018), 54 .
} 
terjadinya proses pembelajaran di dalam kelas, untuk menghubungkan iman dan kehidupan sehari-hari. Pendekatan perkembangan spiritual menekankan proses pendidikan kepada individu-individu yang memiliki berbagai pengalaman pribadi agar bertumbuh imannya kepada Tuhan secara dewasa yang diwujudkan dalam relasinya dengan dunia. Pendekatan komunitas iman menekankan proses pendidikan yang terjadi dalam komunitas, dimana individu-individu bertumbuh dalam komunitas, untuk menjadi komunitas yang melayani keluar.

Pendekatan transformasi sosial menekankan proses pendidikan yang terjadi di tengah masyarakat, dimana terjadi transformasi atau perubahan sosial masyarakat. Keempat pendekatan itu mempunyai sudut pandang yang berbeda antara satu dengan lainnya, namun keempat pendekatan tersebut memiliki karakteristik yang sama yaitu: pertama, masuk ke dalam dunia, bukan meningalkan dunia. Kedua, jemaat setempat adalah konteks utama. Ketiga, refleksi teologis sebagai metodologi. Keempat, pembelajaran religius terjadi dalam keramahan, keadilan dan dalam ruang yang terbuka untuk percakapan dan pengungkapan kebenaran ${ }^{5}$. Dengan demikian konteks mempengaruhi teori. Dalam hubungannya dengan konteks masyarakat multikultural, membutuhkan teori Pendidikan Kristiani untuk menghasilkan situasi yang harmonis, saling menghargai perbedaan dan hidup dalam kesetaraan, antara lain teori yang dikembangkan oleh Barabara Wilkerson. Maka dibawah ini akan menjelaskan teori Pendidikan Kristiani yang berhubungan dengan multikultural dari Wilkerson.

\section{Pendidikan Agama yang Berhubungan dengan Multikultural oleh Barbara Wilkerson}

Barbara Wilkerson adalah seorang konsultan Pendidikan Kristiani untuk gereja dan sebagai pengajar pada Alliance Theological Seminary di Nyack, New York, tempatia melayani sampai masa pensiunnya sebagai wakil Profesor Pendidikan Kristiani. Ia telah menyelesaikan studinya di Princeton Theological Seminary dan menerima gelar doktor dari Universitas Rutgers.

Teori Pendidikan Agama yang berhubungan dengan multikultural oleh Wilkerson dipaparkan dalam buku bunga rampai yang berjudul Multicultural religious education yang diedit oleh Barbara Wilkerson. Buku tersebut diterbitkan oleh Religious Education

\footnotetext{
${ }^{5}$ Tabita Kartika Christiani, Pendidikan Kristiani Berbasis Multikultural (Ungaran: Semarang, 2018), 54-55. Dan Jack L Seymour (ed), Memetakan Pendidikan Kristiani Pendekatan-Pendekatan Menuju Pembelajaran Jemaat (Jakarta: BPK Gunung Mulia, 2016), 146-158.
} 
Press 5316 Meadow Brook Road, Birmingham, Alabama. Dalam buku tersebut Wilkerson bukan hanya menjadi editor dari buku Multicultural Religious Education, namun ia menjadi salah satu penulis dalam buku tersebut. Wilkerson menulis pendahuluan dan satu bagian dari buku tersebut dengan judul Goals of Multicultural Religious Education. Judul tersebut mendapat perhatian dari penulis karena tema tersebut menjelaskan tentang Pendidikan Agama yang berhubungan dengan masyarakat Multikultural. Penulis memberi penjelasan singkat tentang teorinya dan melihat kelebihan serta kelemahannya. Dengan demikian penulis mendapat informasi penting dari teori tersebut dan memberi manfaat bagi penulis.

Penulis juga menyadari bahwa teori Pendidikan Agama yang berhubungan dengan multikultural sudah banyak ditulis dan dibahas oleh para ahli bahkan mereka membangun teori yaitu teori Pendidikan Kristiani dalam Konteks Multikultural yang dibuat oleh Barbara Wilkerson. Menurut Wilkerson tujuan Pendidikan Agama yang berhubungan dengan multikultural secara autentik terdiri dari beberapa hal yaitu:

1. Gereja perlu memahami dan menyadari bahwa keberadaannya di dunia memiliki anggota jemaat yang terdiri dari multi etnis, multi bahasa dll.

2. Gereja perlu membangun sikap positif terhadap keberagaman yang dapat memperkaya iman Kristen dan dapat membawa keutuhan atau kesatuan jemaat, bukan sebaliknya sebagai ancaman terhadap iman Kristen.

3. Gereja perlu memilki sikap menghargai, menilai budayanya sendiri, sehingga gereja dapat menghargai budaya lain.

4. Gereja atau orang Kristen yang menghargai perbedaan dengan pengalaman hidup kekristenannya perlu diwujudkan dalam Pendidikan Kristiani.

Untuk melaksanakan tujuan tersebut di atas, maka gereja atau Pendidikan Kristiani perlu:

1. Membuat kurikulum dan program yang merefleksikan/ mencerminkan keragaman dalam komunitas Kristen.

2. Menekankan praktik hidup keberagaman dengan cara berpartisipasi, sehingga mendorong pengembangan makna kepemimpinan dalam gereja.

3. Membangun komunikasi diantara kelompok etnis lain sebagai realitas dan merayakan tradisi iman dari berbagai agama. 
4. Membangun rasa tanggung jawab terhadap keberagaman melalui dialog dan tindakan iman untuk mewujudkan keadilan bagi semua orang ${ }^{6}$.

Selanjutnya Wilkerson membuat model Pendidikan Agama Multikultural. Menurut Wilkerson, pada umumnya gereja lebih bersifat homogen, namun dalam perkembangannya di era globalisasi gereja mengalami perubahan. Semula gereja bersifat homogen, tetapi sekarang bersifat multikultural. Ketika gereja bersifat multikultural, maka gereja perlu menciptakan lingkungan yang mendukung terjadinya keberagaman. Demikian pula dalam lingkungan Pendidikan Agama yang berhubungan dengan multikultural. Maka Pendidikan Agama (Kristen, penulis) perlu membuat lingkungan yang tepat, kondusif bagi perkembangan gereja dimana terdapat keberagaman etnis, agama, ras dan budaya. Wilkerson mengatakan bahwa dua dari lima faktor yang penting dan efektif dalam Pendidikan Agama Multikultural adalah terciptanya lingkungan yang baik untuk mendukung Pendidikan Agama Multikultural ${ }^{7}$.

Lingkungan bagi sistem Pendidikan Agama Multikultural terdiri dari beberapa faktor. Setiap faktor mempunyai tujuan dan diharapkan membawa pembaharuan bagi sistem Pendidikan Agama Multikultural. Menurut Wilkerson lingkungan Pendidikan Agama Multikultural terdiri dari: ibadah gereja, peraturan gereja, bentuk dan strategi mengajar, program Pendidikan Agama, komunitas yang terlibat, penilaian dan evaluasi, bahan pengajaran, kurikulum, staff pendidik ${ }^{8}$. Wilkerson memberi penekanan pentingnya peran guru atau pendidik. Guru perlu mempersiapkan untuk menjalankan tujuan Pendidikan Agama Multikultural agar murid dapat memiliki sikap terbuka terhadap etnis dan budaya lain 9 . Dengan demikian menurut Wilkerson model Pendidikan Agama Multikultural yang tepat dan efektif adalah pentingnya membangun lingkungan. Lingkungan sangat mempengaruhi proses Pendidikan Agama Multikultural.

Menurut penulis teori Pendidikan Agama Multikultural Wilkerson mempunyai kelebihan antara lain:

1. Teori Wilkerson perlu mendapat apresiasi karena berangkat dari pemahaman konteks Pendidikan Agama yang berhubungan dengan multikultural. Berdasarkan konteks multikultural, ia membangun teori Pendidikan Agama Multikultural.

\footnotetext{
${ }^{6}$ Barbara Wilkerson (ed), Multicultural Religious Education (Birmingham, AL: Religious Education Press, 1997), 26-27.

${ }^{7}$ Ibid., 27.

${ }^{8}$ Ibid., 29.

${ }^{9}$ Ibid., 30.
} 
2. Teori Wilkerson menekankan lingkungan belajar yang diharapkan dapat membentuk sikap murid agar dapat menerima, menghargai dan terbuka terhadap keberagaman etnis, agama, ras dan budaya dalam masyarakat multikultural. Hal ini dapat diterima dan diterapkan bagi konteks Indonesia yang multikultural. Seperti dalam membangun sikap dan tindakan multikultural yang bersumber dari karakter membutuhkan lingkungan belajar yang kondusif, maka dalam Pendidikan Karakter yang efektif dan berhubungan dengan multikultural juga menekankan pentingnya untuk menciptakan lingkungan pergaulan dan persaudaraan seperti sebuah keluarga yang saling menghargai antara satu dengan lainnya ${ }^{10}$.

3. Penekanan guru dan isi pembelajaran, kurikulum, strategi belajar dll. Dapat membantu untuk menghasilkan sikap murid yang terbuka, menerima dan menghargai perbedaan dalam masyarakat multikultural.

4. Perumusan tujuan Pendidikan Agama Multikultural yang menyeluruh.

5. Pendidikan Agama Multikultural bukan hanya pada tataran empiris atau lingkungan Pendidikan Agama, namun perlu diwujudkan dalam konteks belajar mengajar kepada peserta didik agar membentuk sikap dan tindakan konkrit dalam memahami, menyikapi dan menghargai perbedaan dalam masyarakat multikultural.

Sedangkan kelemahan Pendidikan Agama yang berhubungan dengan multikultural dari Wilkerson adalah:

1. Penekanan pada guru untuk memberikan pemahaman kepada peserta didik tentang keberagaman sangat baik, namun jika Pendidikan Agama Multikultural diterapkan dalam konteks di Indonesia seperti di sekolah, maka guru akan mengalami kesulitan untuk memahami, menguasai tentang berbagai agama di Indonesia. Persoalan ini disebabkan guru tidak menguasai dan dilengkapi dengan teologi agama-agama pada waktu studi. Seperti yang dikatakan Jan S. Aritonang bahwa tanpa pemahaman yang memadai terhadap agama-agama lain bagi seorang pengajar, maka akan sukar sekali menghargai kemajemukan budaya yang disumbangkan dari masing-masing agama peserta didik dalam memperkaya budaya bersama ${ }^{11}$.

2. Kurikulum yang dibangun dengan dasar keberagaman oleh Wilkerson belum begitu banyak dibuat oleh para ahli pendidikan di Indonesia. Persoalan ini disebabkan di

\footnotetext{
${ }^{10}$ Doni Koesoema Albertus, Strategi Pendidikan Karakter Revolusi Mental dalam Lembaga Pendidikan (Yogyakarta: Kanisius, 2015), 53.

${ }^{11}$ Jan S Aritonang, Belajar Memahami Sejarah di Tengah Realitas (Bandung: Jurnal Info Media, 2008), 17 .
} 
Indonesia pembuatan kurikulum tidak lepas dari intervensi pemerintah. Di Indonesia kelompok mayoritas lebih mendominasi kelompok minoritas sehingga untuk membuat kurikulum berbasis keberagaman masih sedikit, meskipun kesadaran dan wacana keberagaman sering dibicarakan dalam forum formal maupun informal tetapi dalam implementasinya masih jauh dari harapan.

3. Penekanan pada peran guru untuk menciptakan lingkungan yang baik sangat dibutuhkan, namun peran murid tidak dapat dilepaskan. Pengalaman murid perlu dihargai dan menjadi sumber pembelajaran karena murid mendapat informasi, pengalaman dari hidup keagamaan di keluarga dan masyarakat yang beragam. Proses Pendidikan Agama Multikultural tidak hanya berpusat pada guru, namun dialog dan interaksi dengan murid sangat penting untuk menghasilkan proses belajar mengajar keagamaan dan multikultural yang tepat dan kontekstual. Maka peran guru untuk menciptakan lingkungan yang nyaman, perlu diwujudkan dalam sebuah komitmen untuk menghapuskan sikap segregasi dan diskriminasi terhadap peserta didik, juga pentingnya guru untuk menjembatani berbagai perbedaan, baik antara guru dengan siswa, maupun antara peserta didik ${ }^{12}$.

4. Proses belajar keagamaan dan multikultural tidak hanya berpusat pada guru tetapi murid sangat penting. Murid dapat menjadi sumber bahan ajar keberagaman yang telah diterima dari keluarga, sekolah dan masyarakat. Dengan demikian proses belajar mengajar yang dilakukan guru menjadi kontekstual. Guru dan murid melakukan dialog untuk mendapatkan ide atau gagasan yang relevan untuk membuat keputusan yang tepat dalam rangka membangun Pendidikan Agama (Kristen) yang multikultural dan kontekstual $^{13}$.

5. Penekanan pentingnya lingkungan bagi Pendidikan Agama yang berhubungan dengan multikultural. Hal ini dapat dipahami dan diterima karena dengan lingkungan yang kondusif dapat mempengaruhi dan membentuk sikap seseorang/ murid menjadi terbuka terhadap keberagaman atau multikultural. Namun pengaruh lingkungan saja belum cukup. Murid perlu memiliki kesadaran, pemahaman yang benar tentang keberagaman hidup keagamaan dalam masyarakat multikultural seperti di Indonesia. Kesadaran yang baik dan melakukan refleksi kritis terhadap keberagaman menghasilkan sikap kemandirian, bukan karena lingkungan yang baik saja, tetapi sikap dan tindakan hidup

\footnotetext{
${ }^{12}$ H.A.R Tilaar, Perubahan Sosial dan Pendidikan Pengantar Pedagogik Transformatif (Jakarta: Grasindo, 2012), 491.

${ }^{13}$ Paulo Freire, Pendidikan Kaum Tertindas (Jakarta: LP3ES, 2008), 77.
} 
keagamaan dalam masyarakat multikultural diputuskan berdasarkan kesadaran diri murid ketika melakukan refleksi teologis terhadap proses Pendidikan Agama yang berhubungan dengan multikultural. Dengan demikian proses kritis dialektis yang menghubungkan antara pendekatan lingkungan (sosialisasi) dan edukasi (sikap kritis) dapat menjadi solusi bagi Pendidikan Agama Multikultural yang efektif dan produktif.

Dengan demikian teori Wilkerson memiliki kelebihan dan kelemahan. Teori Wilkerson dapat bermanfaat bagi proses Pendidikan Agama yang berhubungan dengan multikultural di Indonesia, meskipun perlu mendapat refleksi kritis agar teori ini semakin fungsional dan relevan ketika diterapkan dalam konteks Pendidikan Agama yang berhubungan dengan multikultural di Indonesia.

\section{Tanggapan terhadap Pendidikan Agama Multikultural oleh Barbara Wilkerson}

Konteks atau masyarakat Amerika menjadi perhatian dari Wilkerson, dimana negara Amerika Serikat yang semula monokultural menjadi multikultural karena adanya para imigran yang melakukan migrasi dari berbagai penjuru dunia datang ke Amerika Serikat, terutama kelompok dari Eropa. Peristiwa itu terjadi disekitar tahun 1960-1970'an dimana para imigran harus dapat menerima dan menyesuaikan diri dengan peraturan setempat yang membedakan kelompok pendatang dan kelompok setempat yang mendahului atau pertama (meskipun bukan bangsa pribumi - suku Indian), bahkan terjadi "penindasan kultur" sehingga para imigran memiliki sikap kurang percaya diri atau inferioritas.

Para pegiat pendidikan Multikultural seperti Barbara Wilkerson memberi perhatian agar memberikan pendidikan yang layak bagi para pendatang dengan menghargai kultur yang berbeda, sehingga para imigran dapat merasakan kebanggaan karena budayanya dapat diterima dengan selayaknya oleh kelompok lain. Dengan kata lain melalui pendidikan (agama) multikultural dapat terjadi interaksi yang baik, dimana terjadi sikap yang saling menghargai, menghormati dan menuju pada kesetaraan etnis dan ras. Pendidikan multikultural yang terjadi pada abad 20 dapat dibagi dalam tiga fase: di awal abad 20 berhubungan dengan migrasi orang-orang Eropa ke benua Amerika; fase kedua pada masa Perang Dunia ke II berhubungan dengan; dan pada masa sesudahnya yang 
berhubungan dengan perjuangan kesetaraan ras dan warna kulit ${ }^{14}$. Wilkerson menyadari bahwa multikultural tidak hanya terjadi di wilayah umum atau sekolah, namun gereja juga mengalami multikultural, sehingga gereja perlu membangun pendidikan agama multikultural.

Konteks Amerika Serikat yang dilihat oleh Wilkerson berbeda dengan yang dialami dan dilihat oleh Antone sebagai orang Asia sekaligus (orang Filipina), dengan konteks Asia yang meliputi keberagaman bukan terbatas pada ras dan etnis saja, namun meliputi etnis, ras, agama, budaya, ketidakadilan, penindasan, kemiskinan, perbedaan ideologi dll atau pluralisme ${ }^{15}$. Sehingga konteks pendidikan multikultural atau kemajemukan yang dilihat oleh Wilkerson dan Antone mempengaruhi dalam membangun teori pendidikan agama yang berhubungan dengan multikultural. Demikian pula dengan konteks Indonesia sebagai bagian dari Asia, maka konteks Indonesia lebih "dekat" dengan Antone (Filipina) daripada Wilkerson yang punya konteks Amerika Serikat. Namun bukan berarti teori Wilkerson tidak dapat diterapkan dalam konteks pendidikan agama multikultural di Indonesia. Sebaliknya bahwa Wilkerson yang punya konteks Amerika Serikat dimana masyarakat setempat mayoritas beragama Protestan, maka teori Pendidikan Agama Multikultural yang dibangun oleh Wilkerson lebih melihat dari perspektif Kristiani.

Di satu sisi teori Wilkerson sangat terbatas pada pemahaman atau dari perspektif Kristiani, namun di sisi lain, juga menjadi kekuatan sebagai komunitas Kristiani yang peduli dengan keberagaman atau multikultural yaitu memperjuangan hak yang setara diantara budaya yang ada. Dengan kata lain prinsip multikultural sebagai perjuangan hak kesetaraan dapat menjadi inspirasi bagi usaha membangun pendidikan agama multikultural di Indonesia. Sedangkan teori yang dibangun Antone lebih kepada konteks pluralisme yang menekankan adanya sikap toleransi, menerima, menghargai perbedaan agama. Dengan demikian antara Wilkerson dan Antone mempunyai sedikit perbedaan yaitu konteks pluralisme yang menghendaki adanya sikap toleransi beragama, sedangkan Wilkerson dengan konteks multikultural mengusahakan adanya perjuangan hak yang setara bagi pendidikan agama multikultural.

Kedua teori yang dibangun oleh Wilkerson dan Antone berdasarkan konteks dapat membawa suatu pembedaan antara konteks agama dan kultur, maka Banks memberi

\footnotetext{
${ }^{14}$ Tabita Kartika Christiani, Pendidikan Kristiani Berbasis Multikultural (Ungaran: Semarang, 2018). Dan Barbara Wilkerson (ed), Multicultural Religious Education (Birmingham, AL: Religious Education Press, 1997), 2-4.

${ }^{15}$ Hope S Antone, Pendidikan Kristiani Kontekstual Mempertimbangkan Realitas Kemajemukan Dalam Pendidikan Agama (Jakarta: BPK Gunung Mulia, 2010), 6.
} 
pengertian yang lebih baru bahwa antara kultur dan agama tidak perlu dibedakan, agama bagian dari kultur. Seperti yang dikatakan Banks bahwa Pendidikan Multikultural bertujuan untuk menciptakan pendidikan yang setara bagi kelompok yang berbeda, baik dari latar belakang gender, ras, etnis, kelas sosial, bahasa, agama dan budaya ${ }^{16}$.

Dengan demikian teori di atas baik Wilkerson, Antone dan pemahaman Banks tentang tidak adanya pembedaan antara agama dan kultur, menjadi inspirasi bagi konteks di Indonesia untuk membangun Pendidikan Agama yang berhubungan dengan kemajemukan agar dapat menciptakan sikap dan tindakan menghargai, menerima atau toleransi terhadap perbedaan agama, namun sekaligus dalam Pendidikan Agama Multikultural bertujuan untuk membangun hidup berdampingan yang setara, sehingga ada perjuangan hak yang setara. Dengan kata lain prinsip toleransi dalam pluralisme dan perjuangan hak yang setara dalam multikultural tidak perlu dibedakan karena keduanya masuk dalam pemahaman multikultural dan sama pentingnya untuk diperjuangkan demi keberadaan bangsa Indonesia yang adil dan damai dalam konteks masyarakat multikultural.

\section{Pendekatan Pendidikan Agama Wilkerson}

Wilkerson memakai pendekatan dengan menciptakan lingkungan sekolah maupun gereja yang kondusif agar proses pendidikan agama multikultural dapat berlangsung dengan baik, sehingga menghasilkan peserta didik atau masyarakat yang dapat saling menghargai berbagai budaya atau multikultural. Pendekatan Wilkerson yang menekankan pentingnya lingkungan menurut penulis dari perspektif Pendidikan Kristiani dapat dikelompokan pada pendekatan sosialisasi. Proses sosialisasi dalam Pendidikan kristiani dimaksudkan sebagai cara membentuk identitas Kristiani atau iman Kristiani dengan cara menyesuaikan diri dengan lingkungan sekitar yang mempengaruhi seseorang atau kelompok tanpa ada usaha untuk mengubah atau mengganti yang sudah ada ${ }^{17}$.

Pendekatan-pendekatan yang bersifat sosialisasi dan edukasi (Pendidikan) istilah yang dipakai Atmadja dari Groome ${ }^{18}$ berbeda dengan pendekatan lain yang lebih baru seperti yang dikemukakan oleh Seymour dengan empat pendekatan dalam Pendidikan

\footnotetext{
${ }^{16}$ James A Banks \& McgeeBanks Cherry A (eds), Multicultural Education: Issues and Perspectives (New York: John Willey \& Sons, 2001), 25.

${ }^{17}$ Atmadja Hadinoto, N.K, Dialog Dan Edukasi Keluarga Kristen Dalam Masyarakat Indonesia (Jakarta: BPK Gunung Mulia, 1990), 184.

${ }^{18}$ Thomas H Groome, Christian Religious Education, Pendidikan Agama Kristen, Berbagi Cerita dan Visi Kita (Jakarta: BPK Gunung Mulia, 2010), 169 \& 178.
} 
Kristiani yang berlainan namun antara satu dengan lainnya saling berhubungan yaitu pendekatan instruksional, pendekatan spiritual, pendekatan komunitas iman dan pendekatan transformasi sosial. Pendekatan Sosialisasi dan edukasi (pendidikan/ pengajaran) dianggap untuk memudahkan dua ekstrim yang berbeda dan untuk memberi tanggapan dari pendekatan Wilkerson yang menekankan pendekatan lingkungan (proses sosiaisasi) yang kondusif bagi proses belajar untuk membentuk pribadi yang multikultural melalui pendidikan agama multikultural.

Pendekatan sosialisasi sudah lama dilakukan oleh Pendidik dalam Perjanjian Lama karena pada waktu itu belum ada pendidikan formal. Pendidikan banyak terjadi dalam keluarga (Ulangan 6:1-8), dimana orang tua menjadi guru dan mengajarkan tentang perbuatan Allah yang besar. Contoh peristiwa tentang Allah membawa umat Israel keluar dari Mesir dan perbuatan-perbuatan lain Allah yang besar. Pengalaman iman orang tua Israel bersama Allah diceritakan kepada anak-anak mereka. Proses pengajaran iman yang demikian adalah sebuah proses pewarisan iman (transmisi) atau sosialisasi. Tujuan pendidikan iman yang bersifat transmisi adalah untuk membentuk identitas iman seseorang, demikian pula pada periode gereja mula-mula proses pendidikan iman melalui katekisasi yang menunjukan proses sosialisasi. Proses sosialisasi tidak dapat dihindari dalam pendidikan iman karena manusia sendiri adalah makhluk sosial yang membutuhkan orang lain dalam membangun imannya atau dalam komunitas iman ${ }^{19}$.

John Westerhoff III adalah salah satu tokoh Pendidikan Kristiani yang memakai pendekatan sosialisasi, bahkan ia menambahkan sosialisasi yang disengaja atau sebuah proses enkulturasi untuk membangun identitas iman individu. Westerhoff III mempunyai pemahaman bahwa pendidikan sebagai aspek dari sosialisasi yang mencakup semua usaha yang sengaja, sistematis dan terus-menerus untuk mentransmisikan atau membangkitkan baik pengetahuan, sikap, nilai-nilai, tingkah laku dan atau kepekaan-kepekaan ${ }^{20}$. Dapat dikatakan bahwa pendidikan adalah sebagai salah satu agen dari begitu banyak sosialisasi dalam suatu persekutuan masyarakat.

Selanjutnya pendekatan pengajaran (pendidikan/ edukasi) menurut Westerhoff III dapat disamakan dengan setting pendidikan formal yang namanya sekolah, dimana terjadi bentuk atau model pengajaran. Dalam model demikian dibutuhkan guru yang profesiaonal yang memahami anak didik, organisasi kelas, metode yang efektif bagi proses belajarmengajar, kurikulum dan sarana lain. Kedua pendekatan di atas masing-masing

\footnotetext{
${ }^{19}$ Ibid., 178.

${ }^{20}$ Ibid., 176.
} 
mempunyai kelemahan dan kelebihan. Secara singkat bahwa pendekatan sosialisasi lebih banyak menekankan pada sikap (afektif) dan tindakan, sedangkan dimensi kognitif kurang mendapatkan penekanan yang seimbang. Sehingga pendekatan sosialisasi kurang menekankan berpikir secara kritis.

Sedangkan pendekatan sosialisasi dapat membentuk identitas Kristiani, dengan identitas Kristiani maka iman dimungkinkan mengalami pertumbuhan. Groome sangat tidak setuju jika pengajaran (pendidikan) hanya sebagai salah satu bagian dari pendekatan sosialisasi, namun ia juga tidak menyangkal bahwa dengan pendekatan sosialisasi dapat membentuk identitas Kristiani yang memungkinkan adanya pertumbuhan iman. Sebaliknya Groome juga melihat bahwa melalui pedekatan pengajaran (edukasi) menghasilkan kesadaran dan cara berpikir secara kritis bagi identitas persekutuan Kristiani. Maka Groome melakukan hubungan kritis dialetis diantara kedua pendekatan tersebut dengan alasan kesadaran kritis sangat dibutuhkan bagi pembaharuan masyarakat ${ }^{21}$.

Pada umumnya gereja lebih bersikap eksklusif terhadap masyarakat sekitar. Pemahaman pendekatan sosialisasi adalah bahwa pembaharuan iman atau kedewasaan iman dapat terjadi dari pengaruh atau adanya proses sosialisasi dari lingkungan atau lembaga-lembaga Kristiani, padahal lembaga Kristiani atau masyarakat kristiani dalam konteks di Indonesia (konteks Amerika sekarang juga multikultural) yang plural jumlahnya sangat kecil. Selain jumlah yang kecil, jumlah orang Kristen di Indonesia terdiri dari berbagai kelompok atau profesi (partai politik, etnis, ideologi, dll) sehingga belum tentu nilai-nilai kekristenan yang diutamakan. Masing-masing kelompok memiliki nilai-nilai yang berbeda bahkan dapat bertentangan dengan nilai kekristenan, sehingga proses sosialisasi yang diharapkan dapat bertentangan dengan nilai kekristenan.

Pendidikan Kristiani perlu memberikan refleksi kritis terhadap nilai-nilai yang bertentangan dengan nilai kekristenan. Dengan demikian pendekatan edukasi yang menekankan kekritisan dalam berpikir menjadi kebutuhan yang sangat mendesak bagi warga gereja dalam menghadapi pluralitas dan multikultural khususnya di Indonesia, serta dalam menghadapi globalisasi. Dengan kata lain sulit untuk menerima pendekatan sosialisasi dalam konteks di Indonesia yang pluralis dan multikultural, justru sebaliknya warga gereja perlu diperlengkapi dengan sikap kritis terhadap persoalan masyarakat seperti

${ }^{21}$ Ibid., 180. 
keberagaman, radikalisme, korupsi yang merajalela dan membenarkan masyarakat apa adanya $^{22}$.

\section{Pentingnya Pembaharuan Gereja}

Groome mengatakan bahwa pendidikan yang menekankan kekritisan sangat diperlukan bagi usaha pembaharuan gereja. Keberadaan gereja didunia ini secara eksistensial belum mewujudkan gereja yang sebenarnya. Gereja sedang dalam perjalanan menuju kepada kesempurnaan dalam Kerajaan Allah. Gereja perlu terbuka terhadap perubahan. Pada umumnya gereja mengalami proses sosialisasi untuk kepentingan kelompoknya, sehingga kelompok menyesuaikan norma-norma kelompok, sedangkan pembaharuan secara anggota/ individu kurang mendapat perhatian akibatnya gereja masuk pada status quo atau stagnan. Kondisi yang stagnan perlu mendapat refleksi kritis agar terjadi pembaharuan untuk memenuhi tuntatan zaman. Proses sosialisasi yang disengaja atau enkulturasi tidak cukup, gereja membutuhkan pembaharuan melalui kegiatan edukasi yang kritis dialektis.

\section{Pentingnya Dialektika Sosialisasi dan Edukasi}

Groome mengatakan tidak cukup hanya mengandalkan proses sosialisasi dalam membangun iman Kristiani yang dewasa. Proses sosialisasi hanya menghasilkan masyarakat gereja yang nampak di luar saja (semacam civil religion) di Amerika Serikat artinya orang Kristen yang tidak punya pendirian yang teguh, hanya mengikuti "trend" yang sedang terjadi dalam gereja, sehingga tidak ada sikap kritis terhadap kondisi gereja yang demikian. Menurut Fowler bahwa tingkat pertumbuhan iman dari tingkat yang satu menuju tingkat selanjutnya membutuhkan proses “dialektis". Jika proses dialektis itu tidak terjadi maka iman itu akan berhenti pada tahap itu (tingkat 3 synthetic-conventionalfaith) artinya iman seseorang berhenti pada tahap peniruan bukan pada arah "ini pendapatku sendiri". 23

Groome mengingatkan bahwa kekritisan itu sangat penting dalam edukasi. Edukasi bukan bagian dari sosialisasi karena itu tidak memuaskan. Jika edukasi menjadi bagian dari sosialisasi maka akan menghasilkan orang-orang yang membebek atau meniru pendapat

\footnotetext{
${ }^{22}$ Atmadja Hadinoto, N.K, Dialog Dan Edukasi Keluarga Kristen Dalam Masyarakat Indonesia. (Jakarta: BPK Gunung Mulia, 1990), 192. Dan Daniel Nuhamara, Pendidikan Agama Kristen Dewasa (Bandung: Jurnal Info Media, 2007), 131.

${ }^{23}$ Thomas H Groome, Christian Religious Education, Pendidikan Agama Kristen, Berbagi Cerita dan Visi Kita (Jakarta: BPK Gunung Mulia, 2010), 184.
} 
orang lain dan bukan pada transformasi manusia yang dewasa serta mandiri. Proses edukasi yang kritis dialektis merupakan usaha sengaja dan terencana. Bagi Pendidikan Kristiani bukan masalah memilih sosialisasi atau edukasi, namun Pendidikan Kristiani memerlukan kedua-duanya ${ }^{24}$.

Dengan demikian pendekatan Wilkerson yaitu dengan penekanan lingkungan (proses sosialisasi) bukan satu-satunya yang sudah lengkap, namun perlu ada pendekatan edukasi sehingga dapat menghasilkan peserta didik atau warga gereja yang mampu berpikir kritis bagi perkembangan pendidikan multikultural di Indonesia. Proses sosialisasi hanya membawa orang pada peniruan dan bukan pada "pendapatnya sendiri" seperti dalam pendekatan edukasi. Maka sosialisasi perlu dilengkapi dengan edukasi. Keduanya menjadi penting bahkan menjadi hubungan dialektis yang saling memberdayakan.

\section{Kesimpulan}

Konteks masyarakat setempat dapat mempengaruhi dan membentuk teori Pendidikan, seperti teori Pendidikan Agama Multikultural dari Wilkerson yang dipengaruhi dan dibentuk oleh konteks masyarakat yang beragam etnis dan ras. Teori Wilkerson punya kekuatan dan kelemahan bagi Pendidikan Agama Multikultural, namun dari beberapa prinsip teori Pendidikan Agama Multikultural diharapkan dapat memberikan kontribusi bagi pegiat Pendidikan Agama Multikultural di Indonesia. Gereja atau lembaga Pendidikan Kristiani diharapkan dapat membangun teori Pendidikan Agama Multikultural yang lebih baru dan kontekstual demi kehidupan bangsa Indonesia yang lebih baik yaitu hidup dalam masyarakat multikultural dimana setiap individu maupun kelompok dari berbagai golongan masyarakat dapat hidup berdampingan secara damai dalam kesetaraan meskipun dalam keberagaman. Masyarakat Indonesia dapat hidup yang saling menghargai, menerima perbedaan dalam kesetaraan sebagai bangsa yang memiliki semboyan berbedabeda tetapi tetap satu yaitu Bhineka Tunggal Ika.

\section{Kepustakaan}

Alkitab. 2011. Jakarta: Lembaga Alkitab Indonesia.

Albertus, Doni Koesoema. 2015. Strategi Pendidikan Karakter Revolusi Mental dalam Lembaga Pendidikan. Yogyakarta: Kanisius.

\footnotetext{
${ }^{24}$ Atmadja Hadinoto, N.K, Dialog Dan Edukasi Keluarga Kristen Dalam Masyarakat Indonesia. (Jakarta: BPK Gunung Mulia, 1990), 193. Dan Thomas H Groome, Christian Religious Education, Pendidikan Agama Kristen, Berbagi Cerita dan Visi Kita (Jakarta: BPK Gunung Mulia, 2010),185-186.
} 
Antone, Hope S. 2010. Pendidikan Kristiani Kontekstual Mempertimbangkan Realitas Kemajemukan Dalam Pendidikan Agama. Jakarta: BPK Gunung Mulia.

Aritonang, Jan S. 2008. Belajar Memahami Sejarah di Tengah Realitas. Bandung: Jurnal Info Media.

Banks, James A \& Cherry A. McgeeBanks (eds). 2001. Multicultural Education: Issues and Perspectives. New York: John Willey \&Sons.

Christiani, Tabita Kartika. 2018. Pendidikan Kristiani Berbasis Multikultural. Ungaran: Semarang.

Freire, Paulo. 2008. Pendidikan Kaum Tertindas. Jakarta: LP3ES.

Groome, Thomas H. 2010. Christian Religious Education, Pendidikan Agama Kristen, Berbagi Cerita dan Visi Kita. Jakarta: BPK Gunung Mulia.

Hadinoto, N.K. Atmadja. 1990. Dialog Dan Edukasi Keluarga Kristen Dalam Masyarakat Indonesia. Jakarta: BPK Gunung Mulia.

Nuhamara, Daniel. 2007. Pendidikan Agama Kristen Dewasa. Bandung: Jurnal Info Media.

Seymour, Jack L (ed). 2016. Memetakan Pendidikan Kristiani Pendekatan-Pendekatan Menuju Pembelajaran Jemaat. Jakarta: BPK Gunung Mulia.

Tilaar, H.A.R. 2012. Perubahan Sosial dan Pendidikan Pengantar Pedagogik Transformatif. Jakarta: Grasindo.

Wilkerson, Barbara (ed). 1997. Multicultural Religious Education, Birmingham, AL: Religious Education Press. 